\title{
Rethinking The Taproot of The Security Challenges In Africa: Bringing Back The Colonial Legacy
}

\author{
Ahmed Badawi Mustapha \\ Research Fellow, Institute of African Studies, University of Ghana \\ Email:abmustapha@ug.edu.gh \\ \& \\ Abdallah Imam Haruna \\ PhD Candidate: International Relations, Social Sciences University of Ankara, Turkey \\ harunaimam@yahoo.com
}

\section{Abstract}

This paper offers a counter-narrative to the constricted Western narratives that often discount how colonial domination, exploitation, and external interference have shaped Africa's past and present, especially in the area of security. It focuses on the numerous security challenges in Africa and its complex historical nexus to the colonial legacy. The piece draws from the variegated dominant arguments and counterarguments on African (in)security issues, colonial rule, and the theoretical security models and concepts. The paper demonstrates, through an exploration of the formation of postcolonial states, that colonialism cannot be excused as some distant root cause of the security problem on the continent, but has deliberately crafted some specific subjects, societies and states that serve to perpetuate the challenges in the security complex of Africa.

Keywords: security, colonial legacy, nation-state, Africa

\section{Introduction}

The African continent is largely regarded as a breeding ground and safe haven for terrorist groups such as the Islamic State and Al-Qaeda in West Africa (largely in Burkina Faso, Mali and Niger), the Ansar al-Sharia in some parts of North Africa (i.e., Libya and Tunisia), Boko Haram in Nigeria, the Lord's Resistance Army in Uganda, and the infamous al-Shabab in Somalia, among others (Le 
Sage, 2010). It is a continent best known for problems such as civil wars, drought, famine, diseases (such as Ebola and HIV/AIDs), migration, and environmental degradation. The continent is over-burdened with both internal and external debts and soaring inflation rates amid fluctuating economic growth (due to corrupt political leaders in most cases). It, unfortunately, cannot survive on its budget without "begging" for donor support; and above all, it is a povertystricken continent in need of charity, whose development should be seen as a moral imperative in the eyes of the philanthropic world. When this catalogue of socio-economic ailments coupled with the weak political systems and the feeble democracy being practised in the continent, the world deems it justified judging Africa as its most insecure region (Cilliers, 2015).

However, the 52 post-colonial new independent nation-states located on the continent of Africa could argue that the source of the contemporary challenges, especially security challenges on the continent should not and cannot be lost to the world - it is a colonial inheritance (Musah \& Fayemi, 2000). Western values, norms and/or culture began to assimilate Africa when foreign invaders - notably - Europeans imposed their imperial ideologies on the continent. During the colonial regimes in Africa, and elsewhere, the main business of state security institutions was to safeguard the parochial interests of the rulers since they were deemed to be under constant threat by those they were forcefully ruling. Since then, African security experts have argued that this practice is visible in state security institutions even long after the decolonisation process had ended (see Kwesi, 2007; Musah, 2009). This paper focuses on the numerous security challenges in Africa and its complex historical linkage to the colonial legacy. The discussion draws from the variegated dominant arguments and counterarguments on colonial legacy in Africa, the (in)security problems in the continent and the theoretical models and concepts in security studies.

The paper takes the view that colonialism cannot be excused as "some distant root cause" of the problem, but an active participant that has deliberately contrived some specific states, societies and subjects that serve as agents for the continuity of challenges in the security sector in the continent (see Lange and Dawson, 2009; Zartman, 1995). The paper does not claim that the colonial legacy is solely responsible for the current security situation in the continent. Rather it seeks to offer a counter-narrative to the confined Western narratives that often discount how colonial domination and external exploitation have helped shape Africa's past and present (see Collier 2009; Collier and Sambanis, 2005; Collier and Hoeffler, 2004; Kalyvas, 2003; Reno 2002). This needs to be accentuated and be brought back into the discussion especially when highlighting the taproot of the security challenges in Africa. The paper explores the nexus 
between colonialism, state formation and insecurity. It then investigates post-colonial security challenges in two key areas namely, terrorism and resource discoveries and how when these clashes with the colonial legacy the eruption is too conspicuous to ignore or discount.

\section{Colonialism, state formation and the insecurity in Africa}

Before we delve into the colonial state formation narratives and how it is impacting on security on the African continent, we would want to briefly look at some of the evolving definitions of security: (1) Traditional security: A traditional security paradigm relies on the concept of Westphalian sovereignty, which establishes the nation-state as the primary actor and assumes a principle of non-interference of one sovereign state in the domestic or internal affairs of another sovereign state. However, with the recent introduction of the principle of R2P (Responsibility to Protect), intervention is possible under some circumstances. (2) Regime security: In post-colonial Africa, contested legitimacy led to structures designed to protect the regime in power and keep it intact, rather than impartially protecting the citizens. (3) Human Security: developed in 1994 by the UNDP in its annual Human Development Report, the human security paradigm focuses on individual security. (4) Citizen Security: a concept that was developed as a response to violence related to drug trafficking and organized crime in Latin America. (5) Security of the individual: This view of security offers a theoretical explanation for why the individual should be the primary focus and argues for a reconstitution of the social contract (adopted from ACSC Session 1: Contemporary Security Trends: 2017).

Thomas Hobbes (1968) in the Leviathan offered perhaps, the most constructive definition yet of the state. Unlike Aron (2001: 750) who sees the state as a "collective personality," Hobbes describes the state as an "Artificial Man" who is authorised to give life to the community and/or society. For Hobbes, there is, between the citizenry and the sovereign state, "a social contract." Under the terms and conditions of this contract, the citizenry is supposed to confer on the state the right to hold in trust an identifiable territorial space and to make and enforce existential laws and/or rules as deemed fit to ensure holistic military security, economic independence and political stability. In other words, the said "social contract" is based on such a mutual trust that all parties would have to abide by the set terms and conditions that govern the contract.

In contrast to the Hobbesian state, the borderlines or boundaries of the nation-states in Africa, as indicated by Poku (1996), were delimited by the imperialists without the general consent of the people who were forcefully divided and distributed among the demarcated territories. 
Unfortunately, even long after the emancipation of the continent, these states still bear the bureaucracies associated with the colonial regimes. The structure of the state's machinery, the official languages (e.g., English for British colonies and French for the colonies of France) and the currencies they use still possess the spirit of imperialism (see Clapham 1996). What is more, very few of these colonial-made states (such as Nigeria, South Africa, the Democratic Republic of Congo, Ethiopia, and Egypt) can boast of a population that is large enough to qualify (by European standard) as a middle-sized state. Many of these states are constantly engaged in conflicts due to the colonial legacy of ethnic fragmentation and/or fractionalization around the continent. Indeed, Africa's high rate of ethnic fractionalization and fragmentation also explains a significant part of most of the developmental challenges the continent is bedevilled with (Easterly \& Levine, 1997).

In explaining the state formation in Africa, perhaps, the 1884 Congress in Berlin comes in handy as a good point to start with. The entire political map of present-day Africa was determined during that congress. No African was part of the entire process - from start to finish. The Europeans who laid their illegitimate claims to what is being described as "the last great landmass still awaiting enclosure" did this excluding the entirety of the Africans themselves (Mayall, 1991). The creation of the European version of sovereign states in the African continent came with it, almost, complete compartmentalization of the region with a new political landscape wherein only a few areas on the continent was not colonized. At the end of it all, Africa was left with artificial geographical demarcations with highly divergent and distorted social, traditional and family values (Mayall 1991). As Smith (2002: 110) postulates, that "Even today ... most people acquire their political citizenship through unchosen, often unexamined, hereditary descent, not because they explicitly embrace any political principles ..." In other words, the people are made citizens of states without their expressed consent. Indeed, one of the most noteworthy challenges associated with the creation of these "unnatural" sovereign states was the potential clash between highly diverse political cultures (Ikome, 2012). The 1967 Biafra war in Nigeria is a notable case in point.

Form the above narratives, it is obvious that the problematic security landscape in modern Africa has been shaped - consciously or unconsciously - by, at least, two colonial legacies: the first of which is the way the nation-states on the continent were constructed. The nation-states in Africa (unlike their European counterparts where new nations virtually replaced old empires) emerged from the "tyrannical" and "dictatorial powers" of the colonial rule. Consequently, these states even after independence lack the ethical or moral high ground to produce what Poku, Renwick and Porto (2007) refer to as "constitutive stories". A constitutive story is persuasive in nature, which is 
"meant to inspire a sense of trust and worth among a critical mass of supporters for particular visions of common membership" (Smith, 2003). This, invariably, led to ethnic and class divisions among the citizens of the newly constructed nation-states. Accordingly, the "natural stitch" that knits patriotism to statism has a limited or no role to play in contemporary African statehood; rendering the Hobbesian social contract between the citizenry and the states impossible to fully formulate on the continent.

These narratives are not just academic quibbles. Indeed, it is indisputable that out of "the many attributes on which the stability of developed nations depend, one fact is incontestable: they all stand upon the pillars of robust, resilient, institutions of a legitimate state" (Huntington, 1973). With varying degrees of autonomy, such institutions have been developed to become the "social shock-absorbers" that are needed to safeguard a sovereign state during turbulent and unruly moments. African states lack these robust and resilient institutions because of the way they (the states) were formed or constituted. A robust body of intellectual evidence supports the view that any nation-state with dysfunctional institutions is a state sitting on a time bomb (Morgenthau, 1978). For instance, the work of Francis Fukuyama, one of America most celebrated political theorists, is the most relevant in this discussion. In one of his numerous books, "The Origins of Political Order: From Prehuman Times to the French Revolution" (2011), Fukuyama identifies the three most important "characteristics of institutions that constitute a political order: the state, rule of law and mechanisms of accountability". However, it is in his 2014 courageous book, "Political Order and Political Decay: From the Industrial Revolution to the Globalisation of Democracy" that a remarkable story is told of how "mankind has undergone in the development of the institutions, which constitute the modern state and the contrast between the developed nations and the fledgling states" that are seen in Africa today.

Fukuyama (2014) distinguishes between state-building and nation-building. He associates statebuilding with "the creation of tangible institutions - armies, police, bureaucracies, ministries, and the like". State-building, he argues, can be "accomplished by hiring staff, training officials, giving them offices, providing them with budgets, and passing laws and directives." By contrast, nationbuilding, "is the creation of a sense of national identity to which individuals will be loyal, an identity that will suppress their loyalty to tribes, villages, regions or ethnic groups." Despite this clear-cut distinction between state-building and nation-building, the two are conterminous, and it might be difficult for one to function in toto without the other. While North America and Europe have accumulated years of experience in both state-building and nation-building which, in many ways, is helping them today to live in well-secured societies, the scenario is not the same for the 
African continent which had been under colonial subjugation for close to a century (Huntington, 1973). Interestingly enough, in Fukuyama's own classification, the states in Africa are still in the phase of "clientelism" (emphasis is ours), which dominated the political landscape of the Americas even beyond Pendleton.

Before we delve into the second legacy of colonialism that has also occasioned the undesirable security conditions in the African continent, we would like to reiterate the point that what we are involved in is not merely a scholastic discussion, but rather an analysis of issues that have an utmost influence on the security quagmire in Africa. Closely related to the whimsical manner with which the states were formed, as elaborated earlier, is the unwarranted distribution of traditional ethnic groups among numerous colonial states (Herbst, 2000). We have already given a mite of the arbitrary delimitation of borderlines during the 1884/5 Berlin Conference where a large number of diverse cultures, identities and ethnicities were haphazardly grouped into new states (Clapham, 1996). This conference served as the taproot for the separation of communities with unified histories and rich cultures into fragmented and tiny states. For instance, in African Guerrillas, a book edited by Christopher Clapham, there is a pictorial description (literally) of how the "Somali people of the Horn of Africa" were painfully disassociated from their original clans and nations. A group of people who hitherto were bonded together by their enviable identity, unparalleled historicity and rich cultural heritage, had to undergo a painful surgical split into five different states by their uninvited colonial guests. The north-western part of the territory, which in 1977 became known as the Republic of Djibouti, was first associated with the French empire. The Western Ogaden region, which was annexed by the Ethiopian empire, is still part of modern-day Ethiopia. The current independent state of Kenya was the south-eastern part of the Somali nation under the colony of the British. What is today referred to as the Republic of Somaliland is the amalgamation of two territories - the British Somaliland Protectorate and the Italian Somaliland.

The resultant long-term effect associated with the distribution of unified groups and communities among different smaller nation-states is the possibility of irredentism - "the political desire of nationalists to reunite their separated people in one unified nation-state" (Poku, Renwick \& Porto, 2007). In the case of Somalia, irredentism emerged during the 1950s as the cornerstone of nationalist movements in the country, which strongly advocated the redemarcation of all inherited colonial borderlines in the Horn of Africa. Such nationalist movements had sought "reunification by force of arms". Thus, they had, in many instances, sponsored guerrilla movements in Kenya, Djibouti and Ethiopia. As we struggle to put our thoughts together to strengthen our argument, our home country, Ghana, is battling with 
irredentism. Both Ghanaian Ewe activists and the Togo Government have openly made demands for the renegotiation of boundaries since 1972 (Brown, 1980). Ghana's uncompromised stance regarding the merits (or otherwise) of those claims has provoked recent escalation of the dispute to the point where it nearly marred the processes leading to the country's 2020 presidential and parliamentary elections. Ghana's "Western Togoland Separatists" want the 1956 plebiscite, which facilitated the union between the British-mandated Togoland and the Gold Coast before Ghana's independence on March 6, 1957, to be revisited. The Homeland Study Group Foundation which insists it can achieve Western Togoland's restoration to its 1922 status, through mass mobilization of her human and financial resources, lays claim to about 4 million core members drawn from across the so-description Tans-Volta Togoland. The territory presented by the "restorationists" as their homeland stretches from a city in Ghana's Upper East Region (Kulungugu) to "Keta in the Southern Coast by the Atlantic Ocean" covering a surface area of 34,600 square kilometres. Jeffrey Herbst's indices for irredentism related conflicts in Africa (with cataclysmic effects) are rather alarming. Herbst (2000) postulates that, between 1963 and 1998, Africa has witnessed about 26 -armed conflicts, which had affected $61 \%$ or over 474 million people of the continent's population. Sub-regional distribution of the affected population stood at $29 \%$ in southern Africa, $51 \%$ in North Africa, $46 \%$ in West Africa, $73 \%$ in Central Africa, and $79 \%$ in East Africa.

The 1994 Rwandan genocide (where over one million Tutsis were massacred) can also find "answers in the nature of political identities generated during colonialism, in the failures of the nationalist revolution to transcend these identities, and in regional demographic and political currents that reach well beyond Rwanda" (see Fearon \& Laitin, 2000; Mamdani, 2001; 1996). Cameroon is yet another colonial-created unsecured state. The Germans who ruled that territory till 1916 colonized Cameroon in 1884 . The country was then placed as a mandated territory of the League of Nations after the defeat of Germany and her allies in World War I. Later, Britain and France were given the mandate to manage the affairs of Cameroon (see Mamdani, 1996). The new colonisers divided the territory into two parts with France taking the lion share (three-quarters of the place) and Britain left with the remaining one-quarter. In 1960, however, Cameroon gained independence from her colonisers, and since then English and French remain the official languages of the country. There are over 260 tribes in Cameroon; each of these tribes speaks a distinct dialect of its own. Two Heads of State have governed the country since independence: the first from 1960 to 1982 when the president resigned and handed over to a constitutionallymandated successor who has been manning the affairs of Cameroon since then. However, in recent times, the marriages of convenience between the Anglophone and Francophone territories 
have witnessed some fatal violent clashes. The army in Cameroon is struggling to subdue the English-speaking separatists who are pushing for the formation of a breakaway state called "Ambazonia". The English-speaking minority in Cameroon have long complained about being marginalised by the French-speaking majority. The intermittent disturbances in the country have forced over half a million Cameroonians to flee. This has presented President Paul Biya his biggest national security threat in nearly 40 years of his presidency.

The decades-old "Game of Thrones" in the "Sudans" (South vs. North) is also another interesting scenario to look at. Of course, the "irredentism narrative" would not be justly presented without the separatists-related conflicts in Sudan. After gaining independence from the British in 1956, the black-populated southern region of Sudan agreed to remain united with their Northern counterparts, who are mostly Arab Muslims. The religious representation in the country was distinctly dissimilar with African Traditional Religions and Christianity taking a chunk of the population, and an Arab-Muslim minority of about 8-10\%. These religious differences coupled with cultural diversities between the north and the south led to one of the world's longest civil wars in recent memory. The fighting lasted for 38 years (1955-2005) with a fragile truce between 1973 and 1983 (see Mamdani, 2009). The resultant destruction was immeasurable. Over 2.5 million civilians were estimated to have perished during the conflict (Moschetti, 2017). In 2011, a process of democratisation in Sudan was at its peak. A plebiscite referendum - which was held between 9 and 15 January 2011 - recorded $98.83 \%$ of the total vote cast in favour of secession. On July 9 , the same year, South Sudan was declared independent making it the193rd country in the world and 54th in Africa. These series of epochal events, which were meant to unite the warring factions, were completely undermined by an outbreak of yet another bloody inter-ethnic conflict in 2013. The protagonists in this latest conflict, the Dinka and the Nuer, constitute the two largest ethnic communities in the region. These ethnic-inspired disturbances have increased in recent times, and today there are at least nine other major ethnic rebel groups in the country. This demonstrates that some states in Africa (even long after independence) are still unable to claim the legitimate monopoly of force in the Hobbesian sense, because the ostensible monopoly is contested, as is its legitimacy (Poku, Renwick and Porto, 2007).

\section{The security challenges in Post-colonial Africa}

African statehoods (such as kingdoms and empires) are said to have predated Western civilization as well as the European notion of the state; and yet by imposing the Western model of statehood on the African continent, "European colonialism destroyed Africa's paradigm of 
statehood along with its value systems that were ideally suited" for the people of Africa. The spillover effect in independent Africa is conspicuous enough. The question that even arises is whether Africa is independent (from external control and influence) because the internal affairs of the continent are still being remote-controlled by ex-colonialists. However, for the sake of this discussion, we can pretend that Africa is truly independent. Post-colonial Africa depicts a continent that is not at ease with itself. Decades after independence, the continent is beset by problems such as armed conflicts (West Africa, North Africa and the Sahel, the Great Lakes region and the Horn of Africa), political violence, (Nigeria, Ghana, Kenya, Somalia, South Sudan, Sudan, the DRC and Libya), hunger (Somalia, Zimbabwe, Central African Republic, Eswatini), diseases (cholera, trachoma, onchocerciasis, Ebola) among others. Some of these problems are perennial while others are intermittent. The security implications of these mishaps should not be lost on us. Currently, the security threats in the continent, as identified by Collier (2015), seem entirely distinct. The first is the rising terrorist activities (by radical Islamic jihadist) and the other is the increased natural resource extraction. Given the deep-rooted nature of these threats and the political landscape of the continent, the ill-equipped security forces in Africa are unable to deal with the challenges. This section focuses on these two distinct post-colonial security threats in Africa.

\section{Terrorism in Africa: security threat (I)}

First, we deemed it as a platitude for us to acknowledge the lack of a universally-accepted definition for "terrorism", and that there are, literally, hundreds of different definitions currently in use. Thus, both academic researchers and political pundits and/or policymakers' attempts to fully conceptualise the term "terrorism" have often been thwarted by this issue of a lack of universallyaccepted definition; and by differentiating everyday criminal violence or military action from terrorism (Schmid, 2011; Townshend, 2002). Indeed, it is quite challenging "to find a common denominator to all such events and make a generalisation that does not become meaningless". The main obstacles to forging consensus on the definition of terrorism have concerned acts of terror committed by states, and the distinction between the activities of terrorists and those of freedom fighters. Lexically, the term "terrorism" is seen as the calculated use of violence (or the threat of violence) against civilians to attain goals that are political, religious or ideological in nature; this is done through intimidation or coercion or instilling fear. Contextually, "terrorism can be broadly understood as a method of coercion that utilizes or threatens to utilize violence in order to spread fear and thereby attain political or ideological goals" (United Nations, 2018). In other words, terrorism could be distinguished from other forms of violence by the classic terrorist 
triangle: $A$ attacks $B$, to pressure or convince $C$ to change its position regarding some action or policy desired by $A$. The real intention of the attack is to spread fear and panic among the populace as the violence or threat of violence is aimed at, circumstantially, unsuspecting innocent public or victims, which, in turn, exert undue pressure on those in authority (third party) such as policymakers and/or state institutions to rethink their stance on certain policy decisions. Terrorists in contemporary times employ varied tactics, and arbitrarily aimed at, or target military installations, non-combatant personnel, government officials and civilians, among others.

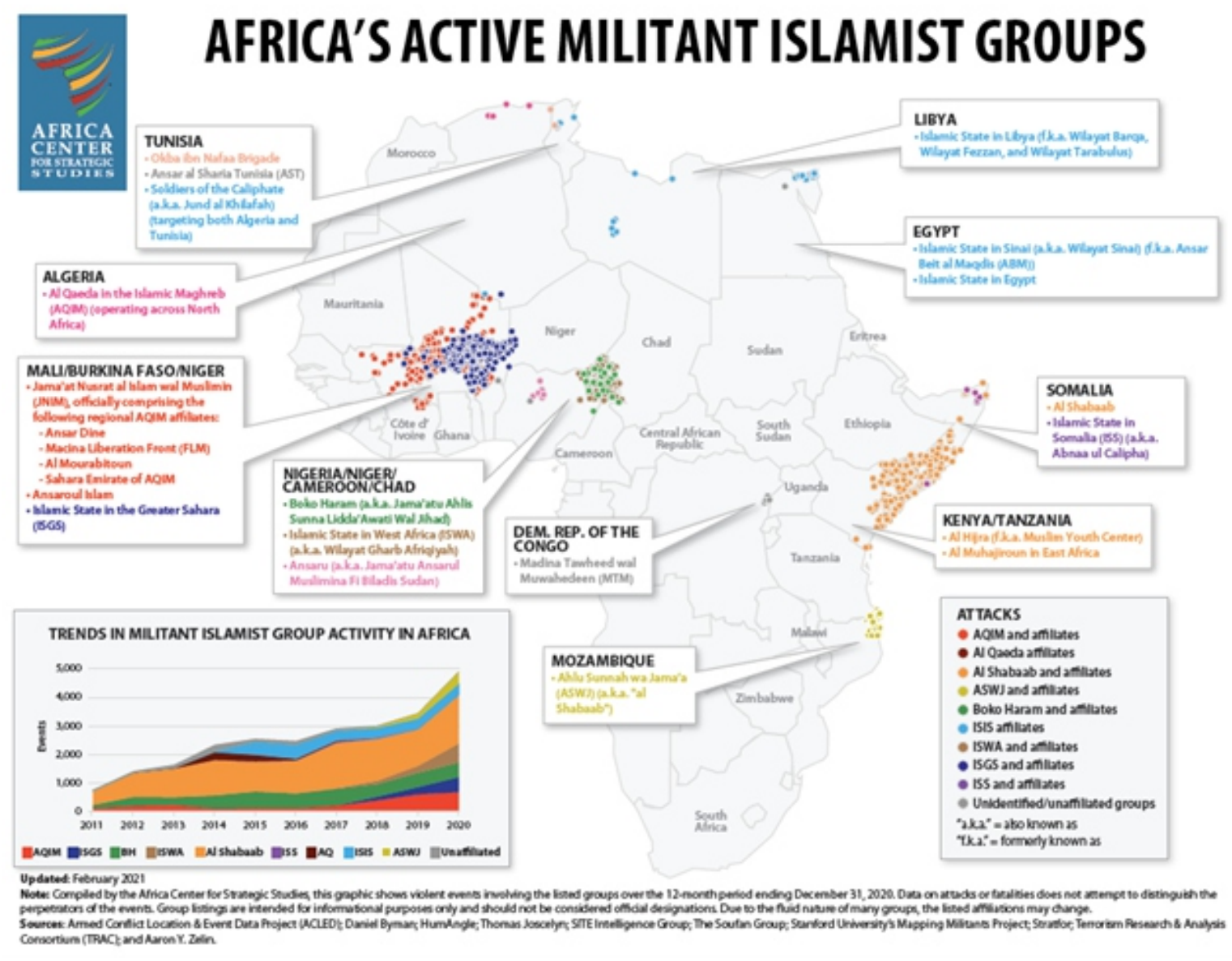

Source:https://africacenter.org/spotlight/spike-militant-islamist-violence-africa-shiftingsecurity-landscape/ 
Terrorism (or some will prefer we call it radical Islamic terrorism) has become a global phenomenon, especially after $9 / 11$. In the context of Africa, as can be seen in Figure 1.1, Terrorism and militancy has been on the rise since 2010 . This scenario presents a distinctive security threat to Africa, in particular, for two main reasons: (1) a lot of the countries in Africa have a significant amount of Muslim populations some of whom can easily be, dangerously, swayed to the side of radicalism due to the current unprecedented high level of poverty and poor governance being witnessed in the continent, (2) also, what makes the terrorist threat quite distinctive is that the institutions, agencies and/or organizations required to effectively forestall the deadly activities of the terrorist lack the needed manpower and resources. The threat from radical Islamic jihadist has recently been evident as can be seen in figure 1.1 above, there is Jama'at Nusrat al-Islam walMuslimin (JNIM) in Mali, the Islamic State in Central Africa operating mostly in the Democratic Republic of Congo, al-Shabaab in Somalia and Kenya, Boko Haram in Nigeria and the Islamic State's West Africa Province (ISWAP) in Niger. Terrorist activities pose existential problems to some of these countries. Without the timely military intervention by the French (itself a contributor to the current trend), both Central African Republic and Mali would have fallen to radical Islamic jihadist.

The case in Mali is much more complicated than meet the eye. Pre-colonial Mali was home to many respected empires on the continent. Timbuktu, a city in the northern part of Mali, was a notable centre for acquiring Islamic knowledge and a key regional trading post for many centuries. However, Mali has since lost this enviable accolade. After gaining independence in 1960 from France, the country suffered a military coup and was under military dictatorship for 23 years. In 2013, upon the request of the government of Mali, France had to intervene militarily to recapture Konna after the city was ransacked and taken over by the Islamic jihadists in the country. And in 2015, there was a United Nations-sponsored ceasefire between the state and the Tuareg separatists. Since then, however, some parts of Mali still remain frail, with the Tuareg rebels sporadically attacking government officials and innocent civilians. The northern and central regions of the country are not spared either. Al-Qaeda-linked militants are carrying out fatal attacks there on anyone who does not share their extremist ideology.

The challenges in Mali would require a multi-dimensional approach; approaches that would look beyond the usual simplistic interventionist agendas. Of course, it is no secret that the actual roots of the current crisis in Mali have been overshadowed by "the dominant war on terror narrative presented in the media". It is worth emphasizing that "beyond the restoration of order and some form of stability, Mali requires responsible and legitimate leadership capable of negotiating long- 
term political solutions. The interim civilian government in Bamako alongside civil society and international actors should use the brief respite afforded to it by the presence of foreign troops to address the endemic corruption and legitimate grievances, which lie at the roots of this multifaceted crisis". The August 2020 coup was not very surprising considering the tense security issues surrounding the country.

Burkina Faso is another vulnerable state in Africa's Sahel Region when it comes to terrorist attacks. As one of the poorest countries in West Africa, Burkina Faso was miraculously spared the violence that hit its northern neighbours (Mali and Niger) until 2015. Some Islamist Jihadists such as al-Qaeda-linked fighters and other groups who associate themselves with the "Islamic State of Iraq and the Levant" (ISIL or ISIS) began to infiltrate the northern part of the country, "before moving east and towards the southern and western borders". The security threat has reignited ethnic and religious tensions, rendering large parts of the country ungovernable. A recent attack in the country had claimed 14 innocent lives. The attack took place in the village of Hantoukoura near the border with Niger in the Eastern Region, an area known for banditry that has come under attack over the past year from groups with suspected links to al-Qaeda and ISIL. The timing of the latest incident, during hours of worship, mirrored other attacks on Christians this year (2019) - a new phenomenon in the West African country that has long prided itself on its religious tolerance.

Even though terrorism does not directly threaten the existence of the states in Kenya and Nigeria, it is undoubtedly damaging their international reputations. In all these scenarios, the radical Islamic terrorism can be seen as a spill-over from the increasing failing statehoods in the continent which makes it quite easier, relatively, for militant groups to recruit and train the teaming unemployed youth, and to build their military capacity with impunity. The on-going tantrum in the State of Libya between the UN-recognised Libyan government and the warlord Khalifa Haftar could provide a safe haven for terrorist groups in the region. The Libyan situation is even more precarious. Two seats of power have emerged in Libya since the overthrow of Muammar Gaddafi in 2011: one in eastern Libya supported mainly by the United Arab Emirates and Egypt, and the Government of National Accord (GNA). The Tripoli-based GNA enjoys the recognition of the United Nations and the international community. Turkey, an influential NATO member, supports the UN-recognized GNA, and has deployed "troops to help defend Tripoli from attack by forces supported by UAE, Egypt and Russia". This could create a "killing field" in the northern part of the continent. In October 2020, however, the two warring rivals inked a UNbrokered nationwide ceasefire agreement in Geneva. It remains to be seen how far the truce will last. 
Contemporary trends and debates in International Relations interrogate the Realists claim that the state still remains the most influential player in global politics, given the myriad of non-state actors (such as the terrorist groups) and the globalized nature of the international system. Adding fuel to such debates are the many states in Africa who fail to correspond to Max Weber's definition of a state "as a human community that successfully claims the monopoly of the legitimate use of physical force within a given territory" (Weber, 1964). The existence of terrorism breaks the state's monopoly of violence, thereby challenging the state as the sole authority on a specific territory. As such, they represent the so-called non-state actors whom Realism, traditionally, paid less attention to in the study of International Relations. John Mearsheimer, one of the card-bearing Realist theories, revealed in an interview when he was asked about the events of $9 / 11$ :

What does a Realist theory of international politics have to say about terrorists? The answer is not a whole heck of a lot. Realism, as I said before, is really all about the relations among states, especially among great powers. ....My theory lof offensive Realism] and virtually all Realist theories don't have much to say about transnational actors. However, there is no question that terrorism is a phenomenon that will play itself out in the context of the international system. So, it will be played out in the state arena, and, therefore, all of the Realist logic about state behaviour will have a significant effect on how the war on terrorism is fought. So Realism and terrorism are inextricably linked, although I do think that Realism does not have much to say about the causes of terrorism (Institute of International Studies, 2002).

From Mearsheimer's response, it is clear that Realists spend less time on thinking about the security threat terrorism poses to the state. Yet, terrorism disrupts the balance of power in ways that confront the theory's normal position. Warlords, for instance, "may often have a significant influence on the direction and duration of many conflicts, due to their, at times, strong power hold over natural resources, enabling them to accumulate more capital than the state leaders."(Baylis, Smith \& Owens 2014: 123) Similarly, they may exert power over large parts of the population when the government is incapable to extend its control to certain areas. Pertinent examples are Boko Haram in Nigeria and al-Shabab in Somalia.

Admittedly, the linkage between the sudden increased terrorist activities and colonial rule can hardly be proven due to some difficulties. First, it is difficult to state that colonialism is the only driven-factor behind the current outnumbered terrorist activities across the African continent. Second, violent confrontations aiming at "political liberations" in the continent have long 
predated the colonial processes. There is no clear-cut finding that delineates or justifies the "colonial-terrorism" thesis. However, it can be argued that colonialism has created some necessary conditions that trigger the use of indiscriminate violence to attain some political goals. As colonialism is deemed the undisputed culprit of the uneven distribution of wealth, the unending poverty and the irredentist movements, so can the current terrorist attacks (which are offshoots of either one or two of these factors) be squarely attributed to colonialism.

\section{Natural resource discoveries: security threat (II)}

At the heart of civil strife and wars in recent times lie natural resources. Huge mining and resource-hungry countries and Multinational Corporations (MNCs) such as BHP Billiton and ExxonMobil manoeuvre for control of immensely valuable mineral lodes and oilfields. Other players like smugglers, arms dealers, shadowy resource traders, corrupt local officials, mercenary companies and transport operators have tremendous influence on the resource war. Such conflicts are further sharpened due to the increasing scarcity of resources, in which influential governments and their official agencies such as the military, the police and some powerful politicians are always deeply involved (see Touray, 2005).

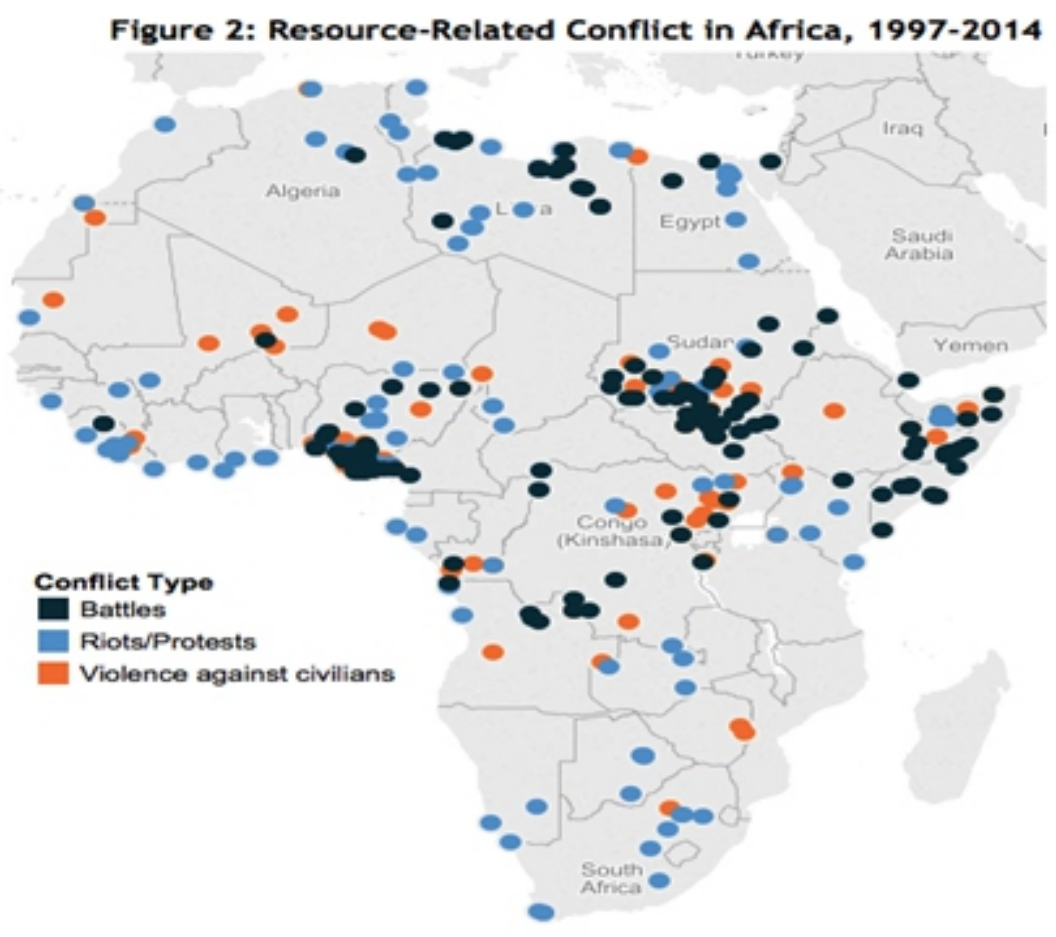

Source: https://acleddata.com/2014/11/19/resource-related-conflict-in-africa/ 
Historically, the African continent has always been an exporter of natural resource (in the form of raw materials) to the industrialized world. However, until recently, the percentage of resource prospecting and extraction was rather on the low side as compared to other parts of the globe. The world has witnessed an exponential increase in commodity prices in the last few decades, which has triggered unprecedented investment in prospecting for natural resources (especially oil) in Africa. Natural resource, to a large extent, is a double-edged sword for most states on the African continent: while it does help in promoting political stability, social cohesion and economic growth, it can equally serve as a catalyst for violent confrontations as well as create opportunities for radicalisation and "warlordism". Thus, with relatively poor economic growth and high indices of violent confrontations, it is fair to ask if the continent is under what is referred to in the academic literature as "resource curse" - a maxim that seeks to suggest "that countries and regions with an abundance of natural resources tend to have slower economic growth, weaker development outcomes, and more instability than resource-scarce countries" (Lundgren, Thomas \& York, 2013). As indicated in figure 2 above from the late 1990s till date, conflict or violence rated to conflict has not only been on the rise but has extended widely across the continent (see figure 3 below). The data collated by The Armed Conflict Location \& Event Data Project (ACLED) from 1997 to 2014 shows that Nigeria is leading with over 300 conflicts related to natural resource issues. South Sudan, Sudan, and Libya Other countries followed in the sequence (See figure 3 below).

Because natural resources have binary implications especially for Africa, these valuable natural resources have, in many cases, served as income generating avenues for traitorous insurrectionists. The cases of countries like Nigeria (oil) Angola and Sierra Leone (diamond) are conspicuous. Given the fact that the colonialists throughout these states in Africa never evenly distributed those natural resources, it is only human that regions with well-endowed resources would want to secede from the nation-state they never even agreed to be part of in the first place. The newly formed South Sudan, the Democratic Republic of Congo's (DRC's) Katanga region and Nigeria's Biafra are just some few examples. 


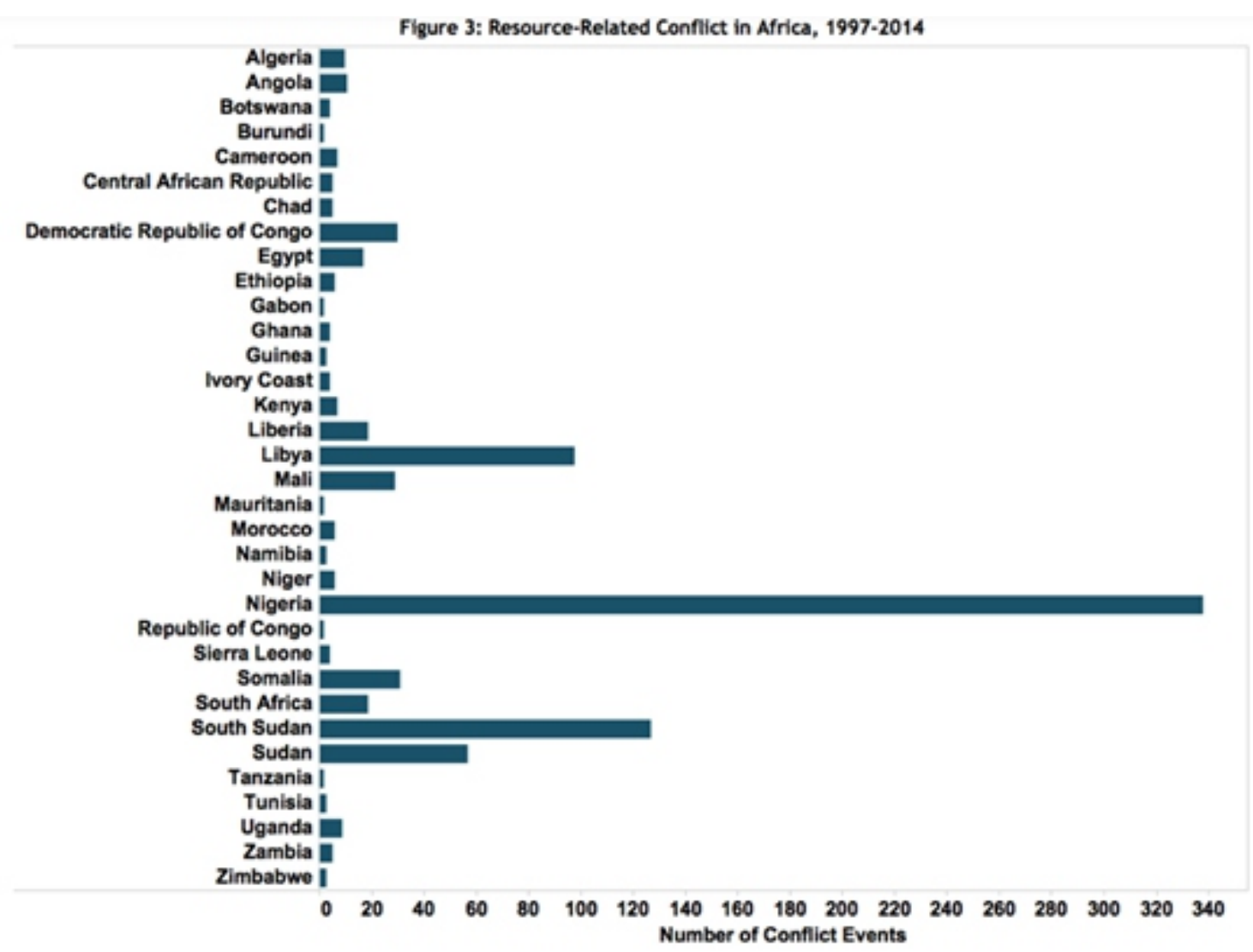

Source: https://acleddata.com/2014/11/19/resource-related-conflict-in-africa/

In Africa, ethnic identities are much stronger than loyalty to the states. Therefore, the interaction of these natural resources and the sub-national identities is likely to generate dangerous friction in the regions where these resources are located. The Turkana people of north-western Kenya were adversely affected by the oil discovery in Kenya on 26 March. These people in that part of the country have never really been integrated into the Kenyan social fabric (Eliza, Leo and Kalipeni, 2015). The discovery accentuated the need to attend to the needs of this neglected populace of Kenya, interestingly, by non-locals within Kenya and foreigners. The joy was, however, short-lived because drilling activities had to be suspended due to violent confrontations by the locals in the area. The discovery has rather exacerbated tensed fissures that led to full-scale violent conflicts between the relegated Turkana and local as well as foreign investors. Also in Tanzania, violent confrontations that have taken place between state forces and residents of Mtwara due to the discovery of gas offshore of that region was precisely because the people in the areas where this natural $r$ has been discovered declared ownership of the discovered gas and would not leave it to the nation (Ahearne \& Childs, 2018; Collier, 2015). Indeed, the natural gas discovery has extended 
the fragmentation of an already "differentiated citizenship" in Tanzania. There is currently an ongoing civil war in South Sudan between the rivals Nuer tribe, and the Dinka as a result of the oil resources in South-Sudan. This has assumed a political dimension with one side (the Dinka) backing President Salva Kiir and the other side supporting Riek Machar, the former Vice President.

\section{Conclusion}

As indicated, we have demonstrated that there are some complex connections between colonialism and the current security challenges in Africa. The colonial political discourse in the continent presents a dual structure that permeates civil society, where a group is pitted against another in an unending tussle (see Majumdar, 2007). Territorial boundaries were hastily drawn, and new forms of identity constructed whose undesirable legacy extends into the present. These narratives, however, are often conspicuously missing in the IR sub-discipline of security studies. It is not unusual to find in the literature that majority of prominent IR scholars who dedicated their active academic lives focusing on the political economy of conflicts in Africa have not seriously considered colonial legacy as being relevant in security studies. What we do see, however, are distorted narratives depicting the continent as 'a scar on the conscience of the entire world', or a continent 'enveloped in the dark mantle of the night'. As Appeltshauser (2016) indicates, "...it is especially cynical that some authors perpetuate the myth of colonial peace, thereby naturalizing conflicts and presenting them as an everyday aspect of African politics (see Mkandawire 2008: 18; Chretien, 1991: 15-17) and veiling the degree of insecurity and suffering that colonial rule has caused in African societies." We are not by this exonerating the present-day corrupt political sycophants from any political or moral responsibility. However, we (and all those in the academia) owe it as a duty to present "a more balanced story, which takes colonial legacies into account, as well as the historical and global context" (Zeleza, 2008, cited in Appeltshauser, 2016).

\section{References}

Ahearne, R. \& Childs, J. (2018). National resources? The fragmented citizenship of gas extraction in Tanzania. Journal of Eastern African Studies, 12(4), 696-715.

Appeltshauser, L. (2016). African in/security and colonial rule: security studies' neglect of complexity. In Peters, I. \& Wemheuer-Vogelaar, W (eds.), Globalizing international relations: scholarship amidst divides and diversity. London: Palgrave Macmillan. 
Aron, R. (2001). The opium of the intellectuals. New Brunswich, NJ:Transaction.

Bayart, J.-F., Ellis, S. \& Hibou, B. (1999). The criminalisation of the state in Africa. Oxford: James Currey.

Brown, D. (1980). Borderline politics in Ghana: The National Liberation Movement of Western Togoland'. The Journal of Modern African Studies, 18, 4, pp. 575-609.

Clapham, C. (1998a). African guerrillas (ed.), Oxford: James Currey.

Clapham, C. (1996). Africa and the international system: The politics of state survival, Cambridge: Cambridge University Press.

Chretien, J. P. (1991). Les Racines De La Violence Contemporaine En Afrique. Politique Africaine 42,15-27.

Cilliers, J. (2015). Future (im)perfect? mapping conflict, violence and extremism in Africa. Institute for Security Studies (ISS), ISS Paper 287.

Collier, P. (2015). Security threats facing Africa and its capacity to respond. PRISM, 5(2), 30-41.

Collier, P. (2009). Research on conflict. Paul Collier's Homepage [Online]. Retrieved 15 December 2019, from: http://users.ox.ac.uk/ econpco/research/conflict.htm.

Collier, P. \& Sambanis, N. (2005). Understanding civil war: evidence and analysis. Washington, DC: The World Bank.

Collier, P. \& Hoeffler, A. (2004). The challenge of reducing the global Incidence of civil war. Copenhagen Consensus 2004 Challenge Paper, Centre for the Study of African Economies, Department of Economics, Oxford University.

Collier, P., Elliott, V.L., Hegre, V.L.H., Hoeffler, A., Reynal-Querol, M. \& Sambanis, N (2003). Breaking the conflict trap: civil war and development policy. Washington, DC: World Bank and Oxford University Press. 
Easterly, W. \& Levine, R. (1997). Africa's growth tragedy: policies and ethnic divisions. Retrieved 20February 2021, from:

https://williameasterly.files.wordpress.com/2010/08/17_easterly_levine_africasgr owthtragedy _prp.pdf

Eliza M. J., Leo C. Z. \& Kalipeni, E. (2015). Oil discovery in Turkana County, Kenya: a source of conflict or development? African Geographical Review, 34:2, pp 142-164, D0I: 10.1080/19376812.2014.884466

Fearon, J. \& Laitin, D. (2000). Violence and the social construction of ethnic identity. International Organization 54(4): pp. 845-877.

Fr. Moschetti, D. (2017). A brief history of the civil war in South Sudan. Retrieved 15 December 2019, from: https://www.combonimissionaries.org/a-brief-history-of-the-civil-war-in-southsudan/

Fukuyama, F. (2011). The Origins of political order: From prehuman times to the French revolution. Farrar, Straus and Giroux.

Herbst, J. (2000a). Economic incentives, natural resources and conflict in Africa. Journal of African Economics, 9 (3), 270-294.

Herbst, J. (2000b). States and power in Africa: comparative lessons in authority and control. Princeton, NJ: Princeton University Press.

Hobbes, T. (1968). Leviathan, C. B. Macpherson, Harmonsworth: Penguin

Huntington, S. P. (1973). Political Order in Changing Societies, Yale: Yale University Press.

Ikome, F. N. (2012). Africa's international borders as potential sources of conflict and future threats to peace and security. Pretoria: Institute for Security Studies. Retrieved 15 December 2020, from: https://africacenter.org/security-article/africas-international-borders-as-potential-sources-ofconflict-and-future-threats-to-peace-and-security/

Kalyvas, S. (2003). The ontology of "political violence": action and identity in Civil Wars. 
Perspectives on Politics 1(3), 475-94.

Kwesi, A. (2007). Africa: confronting complex threats', coping with crisis working paper series. International Peace Academy, New York.

Lange, M. \& Dawson, A. (2009). Dividing and ruling the world? A statistical test of the effects of colonialism on postcolonial civil violence. Social Forces, 88(2), 785-817.

Le Sage, A. (2010). Africa's irregular security threats: challenges for U.S. Engagement. Forum. Institute for National Strategic Studies National Defense University.

Lundgren, C. J., Thomas, A. H. \& York, R. C. (2013). Boom, bust, or prosperity? managing SubSaharan Africa's natural resource wealth. Washington, D.C.: International Monetary Fund.

Majumdar, M. (2007). The subversion of colonial ideology: Jean-Paul Sartre, in postcoloniality: The French Dimension (pp. 83-110). New York; Oxford:Berghahn Books.

Mamdani, M. (2009). Saviors and survivors: Darfur, politics, and the War on terror. HSRC Press. Private Bag X9182, Cape Town, 8000, South Africa.

Mamdani, M. (2001). When victims become killers: colonialism, nativism, and the genocide in Rwanda. Princeton, New Jersey: Princeton University Press.

Mamdani, M. (1996). Citizen and subject: contemporary Africa and the legacy of late colonialism. Princeton, New Jersey: Princeton University Press.

Mayall, J. (1991). The hope and fears of independence, in Rimmer, D. (ed.), Africa 30 Years On. London: James Currey.

Mkandawire, T. (2008). The terrible toll of postcolonial rebel movements: towards an explanation of the violence against the peasantry. In Zeleza, P. and Nhema, A. (eds.) The roots of African conflicts: causes and costs. Oxford: James Currey.

Morgenthau, H. (1978). Politics Among Nations (5th edition). Knopf, New York, NY 